\title{
CORRECTION
}

\section{Correction to: International inter-comparison exercise on ${ }^{153} \mathrm{Sm}$}

\section{J. Jackson ${ }^{1}$ (D - C. Gilligan ${ }^{1}$ - A. V. Davies ${ }^{1} \cdot$ R. Britton ${ }^{1} \cdot$ J. I. Friese ${ }^{2} \cdot$ L. R. Greenwood ${ }^{2}$ - B. D. Pierson ${ }^{2} \cdot$ Z. S. Finch $^{2}$.} B. N. Gartman ${ }^{2}$. D. Dry ${ }^{3}$ I. May ${ }^{3}$. N. C. Smythe ${ }^{3}$ A. J. Gaunt ${ }^{3}$ - E. R. Thomas ${ }^{3}$. K. E. Roberts ${ }^{4}$. N. K. Harward ${ }^{4}$. K. J. Thomas ${ }^{4}$ P. T. Wooddy ${ }^{4}$ (D) P. Zhao ${ }^{4}$

Published online: 11 December 2019

(c) Crown 2019

\section{Correction to: Journal of Radioanalytical and Nuclear Chemistry (2018) 318:107-115 https://doi.org/10.1007/s10967-018-6048-1}

In the original publication of the article, eighteenth author's name was misspelt. The correct name is given in this correction.
Publisher's Note Springer Nature remains neutral with regard to jurisdictional claims in published maps and institutional affiliations.

The original article can be found online at https://doi.org/10.1007/ s10967-018-6048-1.

M. J. Jackson

Mark.J.Jackson@awe.co.uk

1 Atomic Weapons Establishment, Aldermaston, Reading, Berkshire RG7 4PR, UK

2 Pacific Northwest National Laboratory, 902 Battelle Blvd, Richland, WA 99354, USA

3 Los Alamos National Laboratory, Los Alamos, NM 87545, USA

4 Lawrence Livermore National Laboratory, 7000 East Ave., Livermore, CA 94550, USA 